\title{
Autoimmune hemolytic anemia and ovarian dermoid cysts in pregnancy
}

\author{
Afaf A. Felemban, MD, Zuha A. Rashidi, MD, Musab H. Almatrafi, MD, Jawaher A. Alsahabi, MD.
}

\begin{abstract}

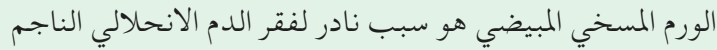

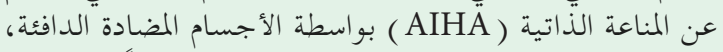

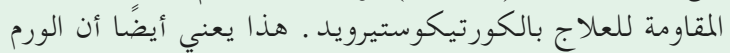

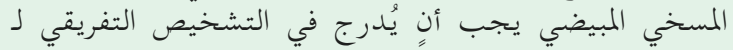

ÄIHA

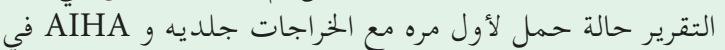

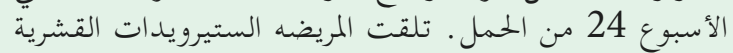

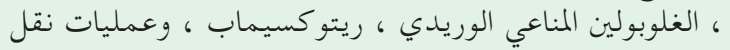

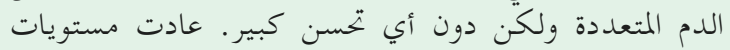

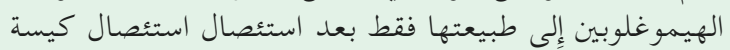

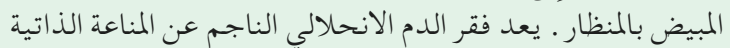

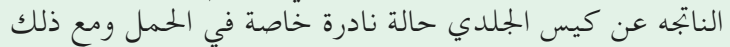

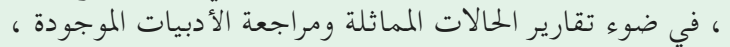

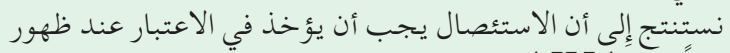

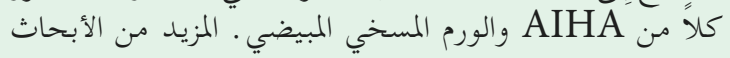

للمرضى الحو امل مطلوبه .
\end{abstract}

Ovarian teratoma is a rare cause of autoimmune hemolytic anemia (AIHA) by warm antibodies, resistant to corticosteroid therapy. This also implies that ovarian teratoma should be included in the differential diagnosis of AIHA, whether or not associated with pregnancy. We present a case of a primigravida who presented with ovarian dermoid cysts and AIHA at 24 weeks of gestation. The patient received corticosteroids, intravenousimmunoglobulin, rituximab, and multiple blood transfusions, with no significant improvement. Hemoglobin levels returned to normal only after laparoscopic ovarian cystectomy. Autoimmune hemolytic anemia caused by dermoid cyst is a rare condition especially in pregnancy. However, in light of similar case reports and review of the existing literature, we conclude that surgical excision should be considered when AIHA and ovarian teratoma coexist.

Saudi Med J 2019; Vol. 40 (4): 397-400 doi: 10.15537/smj.2019.4.24107
From the Reproductive and In Vitro Fertilization Unit (Felemban), and from the Obstetrics and Gynecology (Rashidi, Almatrafi, Alsahabi) National Guard Health Affairs, Riyadh, Kingdom of Saudi Arabia.

Received 8th September 2018. Accepted 20th March 2019.

Address correspondence and reprint request to: Dr. Afaf A. Felemban, Reproductive and In Vitro Fertilization Unit, National Guard Health Affairs, Riyadh, Kingdom of Saudi Arabia.E-mail:Afelemban@hotmail.com

ORCID ID: https://orcid.org/0000-0002-2149-1764

$\mathrm{T}$ There may be several causes of autoimmune hemolytic anemia (AIHA). Rare causes of AIHA are tumors, including ovarian tumors, ${ }^{1,2}$ and these can be either malignant or benign. ${ }^{3,4}$ We present a case of AIHA which developed during pregnancy, associated with ovarian tumor. Autoimmune hemolytic anemia is $\mathrm{IgG}$ Mediated disease for that it is a serious condition for mother and fetus 5 The mechanism of hemolysis in pregnancy has not yet been defined. Agarwal et al in $2003^{6}$ discuss the pattern of such condition and reviewed their clinical course, he reviewed 20 cases of AIHA associated with dermoid cyst, $85 \%$ of them respond to cystectomy after failed corticosteroids and one under went cystectomy shortly after diagnosis who showed some response to steroid management. However, effective treatment in our case was post delivery tumor removal. Thus, it is important for obstetricians/gynecologists to know that teratoma is one of the etiologies of AIHA during pregnancy.

Case Report. A 24-year-old, primigravida was referred to us at 24 weeks of gestation, as a case of AIHA, first diagnosed during pregnancy. Initially she was presented with fatigue and dizziness and low hemoglobin $(\mathrm{Hgb})$ with no history of any medical illness or surgery. She had not been started on any new medications and had no family history of hematological diseases. Initial laboratory tests showed white blood cell (WBC) count $22.9 \times 10^{9} / \mathrm{L}$, red blood cell (RBC) count $2.68 \mathrm{mcL}$, hemoglobin (Hgb) $7.7 \mathrm{~g} / \mathrm{dL}$ (normal: 120-160 gm /L, platelet count 545000 (normal: 150-400X10^9/L), 
reticulocyte percentage 18.63 (normal: $0.5-2.5 \%$ ), lactate dehydrogenase (LDH) 567 U/L (normal: 125243U/L), and total bilirubin 44.1 (normal: 3.4-20.5 umol/L. Kidney function tests were within normal limits, and the direct Coomb's test was positive. Viral serology, anti-nuclear antibodies, anti-double stranded DNA antibodies, anti-lupus, anti SS-A, anti SS-B were all negative. Ultrasound showed a normal fetus with size corresponding to gestational age. However, the maternal right ovary was enlarged, measuring $7.7 \times 7$ $\mathrm{cm}$. A complex cyst measuring $6.7 \times 6 \mathrm{~cm}$ was seen within the ovary, and was thought to be a dermoid cyst (Figure 1).

She received high dose steroids (started by prednisolone $100 \mathrm{mg}$ ) with no significant improvement. Rituximab once a week four doses and intravenous immunoglobulin 3 doses were added, without any success. Hemolysis was refractory a trail of Azathioprine post delivery. Transfusion of multiple packed red blood cells (PRBCs) reached 44 units.

During follow up, the patient received a total of 44 units of PRBC for refractory low Hgb level. At 36-37 weeks of gestation, ultrasound revealed fetal pericardial effusion, and a slightly enlarged dermoid cyst.

Induction of labor was carried out and she uneventfully delivered a healthy baby vaginally. Postnatal echocardiography revealed no pericardial effusion and no other significant abnormalities.

Postpartum, Hgb level dropped from $11.0 \mathrm{~g} / \mathrm{dl}$ to $7.0 \mathrm{~g} / \mathrm{dl}$. Azathioprine and prednisone, along with 6 units of PRBC were transfused. Two weeks later, the patient was seen on outpatient basis, with condition having worsened, with $\mathrm{Hgb}$ level having dropped further, to $6.1 \mathrm{~g} / \mathrm{dl}$.

Laparoscopic right ovarian cystectomy was performed and intraoperative findings of right ovarian dermoid cyst were confirmed on histopathological examination. Postoperatively, she improved significantly; signs and symptoms of anemia reduced and Hgb level increased up to $13.8 \mathrm{~g} / \mathrm{dl}$, while $\mathrm{LDH}$ levels dropped to 169 (Table 1).

Discussion. Association between dermoid ovarian cyst and AIHA is still a rare phenomenon ${ }^{7}$ with a limited number of cases reported in the literature. Ovarian teratomas are relatively common, but the incidence of associated hemolytic anemia is low.

Disclosure. Authors have no conflict of interests, and the work was not supported or funded by any drug company.
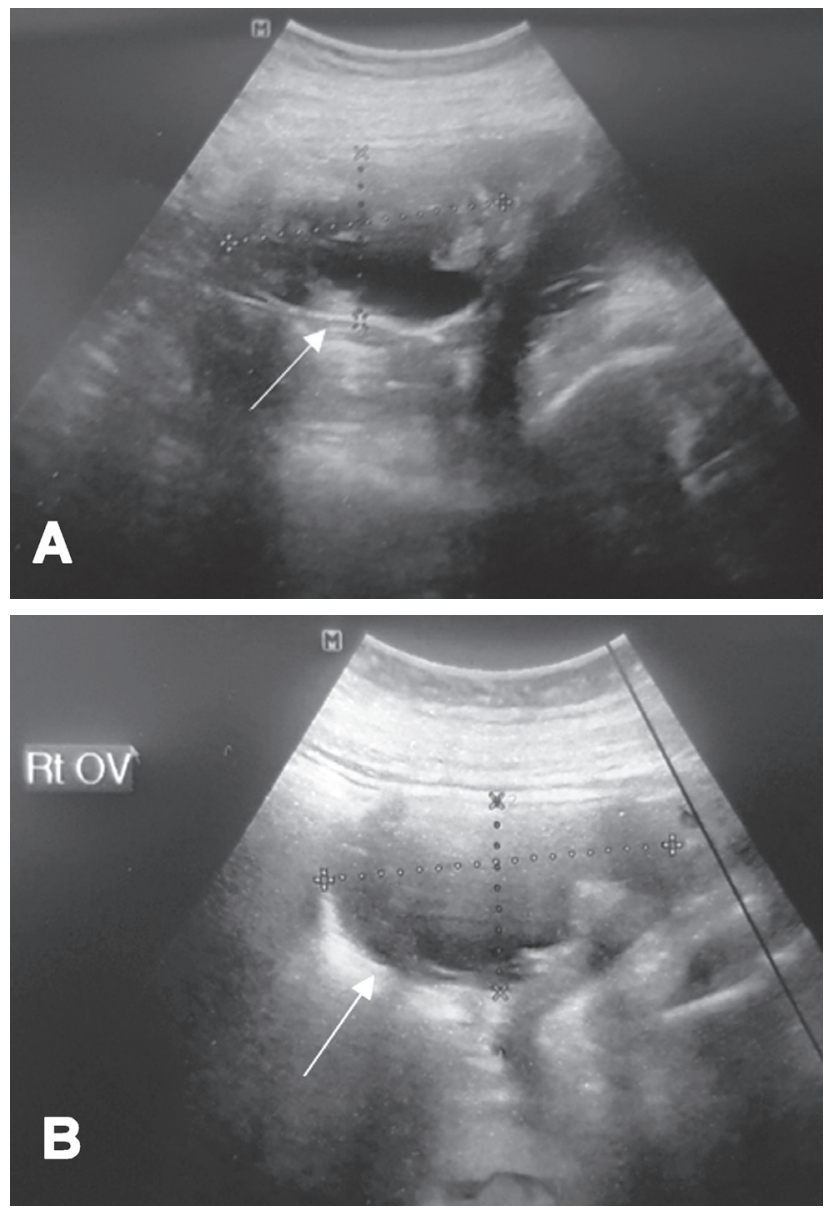

Figure 1 - Right sided ovarian dermoid cyst.

This phenomena was reported by West-Watson and Young ${ }^{8}$ but reported cases are still limited especially in pregnancy. There are different hypothesis describing the immunological reaction triggered by the tumor. Several reports support the hypothesis that the tumor produces antibodies against red blood cells. Antibody production seems to cease immediately after tumor removal in almost all reported cases.?

Glucocorticoids and splenectomy known as the mainstay of treatment of AIHA. In our case; however, it proved to be ineffective. An improvement was seen only after tumor removal. ${ }^{3-6}$ Payne et $\mathrm{al}^{9}$ in 1981 have carried out a literature review of cases reported as dermoid cysts with AIHA, and collected around 19 cases. Sixteen patients responded favorably to tumor removal alone. Negligible response to steroids was reported in 3 patients who required dermoid removal to achieve full response. Antibodies were reported to disappear in 2 weeks to 7 months after tumor removal, which may be considered 
Table 1 - Timeline of summary of the case.

\begin{tabular}{|c|c|c|c|c|}
\hline Date/status & Symptoms/signs & Investigations & Blood transfusion & Intervention \\
\hline $\begin{array}{l}4^{\text {th }} \text { January } \\
24 \text { weeks } \\
\text { pregnant }\end{array}$ & $\begin{array}{l}\text { Initial visit and } \\
\text { referral: } 25 \text { years old } \\
\text { prim gravida } 24 \text { weeks } \\
\text { diagnosed and referred } \\
\text { as AIHA } \\
\text { Complaining of sever } \\
\text { weakness and fatigue } \\
\text { On examination pale } \\
\text { and jaundiced }\end{array}$ & $\begin{array}{l}\text { Hemoglobin } 7.7 \text { (after received } 2 \\
\text { units of packed red blood cells in } \\
\text { her local hospital) }\end{array}$ & None & $\begin{array}{l}100 \mathrm{mg} \text { Prednisone for } 3 \text { days } \\
70 \mathrm{mg} \text { Prednisone (4/1 - 20/1) }\end{array}$ \\
\hline 11 January & $\begin{array}{l}\text { Sever fatigue and } \\
\text { weakness }\end{array}$ & $\begin{array}{l}\text { Hemoglobin }=67 \\
\text { Hematocrit }=0.207 \\
\text { Lactate dehydrogenase }=571 \\
\text { Total bilirubin }=44 \\
\text { Absolute reticulocyte count }=574.4\end{array}$ & $\begin{array}{l}11-17 \text { January } \\
10 \text { units PRBCs (1- } 3 \text { unit } \\
\text { per day ) }\end{array}$ & $\begin{array}{l}\text { Intravenous immunoglobulin } 2 \text { doses of } \\
\text { each } 700000 \mathrm{mg}\end{array}$ \\
\hline $\begin{array}{l}19 \text { January }-5^{\text {th }} \\
\text { February }\end{array}$ & Not documented & $\begin{array}{l}\text { Hemoglobin }=79 \\
\text { Hematocrit }=0.222 \\
\text { Lactate dehydrogenase }=638 \\
\text { Total bilirubin }=36 \\
\text { Absolute reticulocyte count }=492.8\end{array}$ & $\begin{array}{l}22 \text { January - } 28 \text { February } \\
15 \text { units of packed red } \\
\text { blood cell }\end{array}$ & $\begin{array}{l}4 \text { doses Rituximab } 700 \mathrm{mg} \\
50 \mathrm{mg} \text { Prednisone }(20 / 1-26 / 1) \\
40 \mathrm{mg} \text { Prednisone }(27 / 1-1 / 2) \\
30 \mathrm{mg} \text { Prednisone }(3 / 2-6 / 4)\end{array}$ \\
\hline $\begin{array}{l}1^{\text {st }} \text { March } \\
32 \text { weeks }\end{array}$ & Not documented & $\begin{array}{l}\text { Hemoglobin }=76 \\
\text { Hematocrit }=0.218 \\
\text { Lactate dehydrogenase }=646 \\
\text { Total bilirubin }=33.7 \\
\text { Absolute reticulocyte count }=604.8\end{array}$ & $\begin{array}{l}1 \text { st March }-26 \text { March } \\
7 \text { units of packed red blood } \\
\text { cell }\end{array}$ & $\begin{array}{l}\text { One dose intravenous immunoglobulin } \\
20 \mathrm{mg} \text { Prednisone }\end{array}$ \\
\hline $\begin{array}{l}5^{\text {th }} \text { April } \\
37 \text { weeks } \\
\text { pregnant }\end{array}$ & $\begin{array}{l}\text { Induction of labor and } \\
\text { Vaginal delivery }\end{array}$ & $\begin{array}{l}\text { Hemoglobin }=86 \\
\text { Hematocrit }=0.24 \\
\text { Lactate dehydrogenase }=975 \\
\text { Total bilirubin }=33.9 \\
\text { Absolute reticulocyte count }=517.6\end{array}$ & $\begin{array}{l}2 \text { April received } 2 \text { units of } \\
\text { packed red blood cell }\end{array}$ & $\begin{array}{l}\text { Prednisone tapered down to } 5 \mathrm{mg} \text { then } \\
\text { discontinued }\end{array}$ \\
\hline $\begin{array}{l}20 \text { April } \\
2 \text { weeks post } \\
\text { partum }\end{array}$ & Not documented & $\begin{array}{l}\text { Hemoglobin }=73 \\
\text { Hematocrit }=0.222 \\
\text { Lactate dehydrogenase }=921 \\
\text { Total bilirubin }=41 \\
\text { Absolute reticulocyte count }=791.7\end{array}$ & $\begin{array}{l}20^{\text {th }} \text { April received } 2 \text { units } \\
\text { packed red blood cell } \\
1^{\text {st }} \text { May received } 3 \text { units } \\
\text { packed red blood cell }\end{array}$ & Azathioprine for 30 days \\
\hline $\begin{array}{l}8^{\text {th }} \text { May } \\
5 \text { weeks post } \\
\text { partum }\end{array}$ & Complaint of dizziness & $\begin{array}{l}\text { Hemoglobin }=66 \\
\text { Hematocrit }=0.2 \\
\text { Lactate dehydrogenase }=911 \\
\text { Total bilirubin }=50.6 \\
\text { Absolute reticulocyte count }=647\end{array}$ & $\begin{array}{l}9^{\text {th }} \text { May received } 2 \text { units } \\
\text { packed red blood cell } \\
10^{\text {th }} \text { May received } 1 \text { unit } \\
\text { packed red blood cell }\end{array}$ & \\
\hline $\begin{array}{l}10^{\text {th }} \text { May } 5 \\
\text { weeks post } \\
\text { partum }\end{array}$ & & & & Laparoscopic ovarian cystectomy \\
\hline $\begin{array}{l}24 \text { may } \\
2 \text { weeks post } \\
\text { operative }\end{array}$ & $\begin{array}{l}\text { Feeling better no } \\
\text { complaints } \\
\text { Jaundice and pallor } \\
\text { improved }\end{array}$ & $\begin{array}{l}\text { Hemoglobin }=119 \\
\text { Hematocrit }=0.355 \\
\text { Lactate dehydrogenase }=293 \\
\text { Total bilirubin }=17.1 \\
\text { Absolute reticulocyte count }=95.8\end{array}$ & No transfusion required & \\
\hline $\begin{array}{l}13 \text { June } \\
5 \text { weeks post } \\
\text { operative }\end{array}$ & $\begin{array}{l}\text { Feeling better no } \\
\text { complaints }\end{array}$ & $\begin{array}{l}\text { Hemoglobin }=139 \\
\text { Hematocrit }=0.421 \\
\text { Lactate dehydrogenase }=230 \\
\text { Total bilirubin }=12.5 \\
\text { Absolute reticulocyte count }=58.3\end{array}$ & No transfusion required & \\
\hline
\end{tabular}

as a confirmation of the association. ${ }^{9}$ Our patient was pregnant, and literature review did not reveal any case of AIHA due to a dermoid cyst, diagnosed in pregnancy. In fact, cases of AIHA during pregnancy, caused by factors other than dermoid cysts, have been reported late in pregnancy, and lay emphasis on good response to corticosteroids and blood transfusion. ${ }^{5}$
Autoimmune hemolysis in pregnancy complicates 1 in 50000 pregnancies. ${ }^{10}$ In most cases uneventful maternal recovery with good fetal outcome has been reported, except in a few cases caused by autoimmune diseases like systemic lupus erythematosus. ${ }^{10}$ Owing to a lack of similar cases in literature, maternal and fetal course was closely followed, with clinical monitoring of maternal 
1200

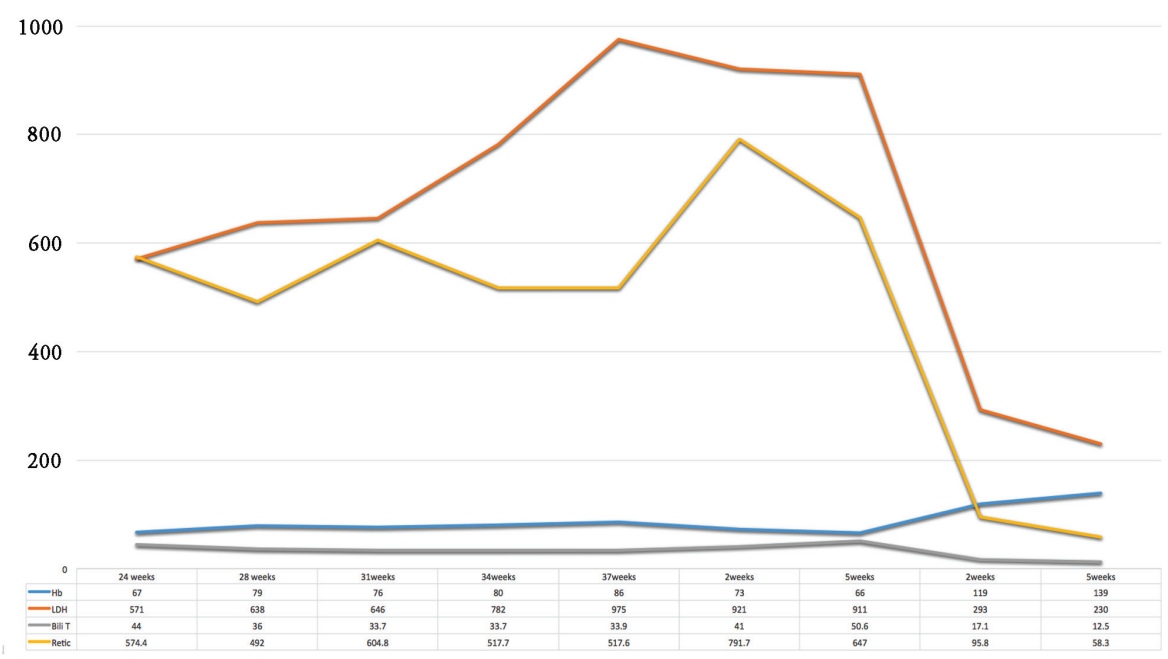

Figure 2 - Laboratory results. $\mathrm{Hb}$ - hemoglobin (g/dl). LDH - lactate dehydrogenase (U/L), Bili T - total bilirubin, Retic - reticulocyte percentage

condition by symptoms and laboratory investigations, and keeping a watch for possible fetal anemia. An obstetric ultrasound showed fetal pericardial effusion at 37 weeks of gestation. However, the fetus was born in a good condition, with normal echocardiography 2 weeks after birth. Unfortunately, the maternal condition did not improve and she required repeated blood transfusions post delivery. Laparoscopy dermoid cystectomy was carried out, after which, complete recovery of the mother took place (Figure 2).

In conclusion, AIHA caused by a dermoid cyst is a rare condition. However, in light of similar case reports and review of the existing literature, it would be reasonable to conclude that in the presence of AIHA and ovarian teratoma, surgical excision should be considered. However, it should be kept in mind that this association may occur during pregnancy. Furthermore longer follow, up duration is needed to actually prove that the ovarian tumor resection led to persistent resolution of AIHA.

Acknowledgment. We would like to acknowledge Dr. Hytham Alsum, Consultant, Maternal Fetal Medicine, National Guard Health Affairs, Riyadh, Kingdom of Saudi Arabia and the Editage.com for the English editing.

\section{References}

1. Jung CK, Park JS, Lee EJ, Kim SH, Kwon HC, Kim JS, et al. Autoimmune hemolytic anemia in a patient with primary ovarian non-Hodgkin's lymphoma. J Korean Med Sci 2004; 19 : 294-296.
2. Sallah S, Sigounas G, Vos P, Wan JY, Nguyen NP. Autoimmune hemolytic anemia in patients with non-Hodgkin's lymphoma: characteristics and significance. Ann Oncol 2000; 11: 1571-1577.

3. Glorieux I, Chabbert V, Rubie H, Baunin C, Gaspard MH, Guitard J, et al. [Autoimmune hemolytic anemia associated with a mature ovarian teratoma]. Arch Pediatr 1998; 5: 41-44.

4. Kim I, Lee JY, Kwon JH, Jung JY, Song HH, Park YI, et al. A case of autoimmune hemolytic anemia associated with an ovarian teratoma. J Korean Med Sci 2006; 21: 365-367.

5. Laužikienė $D$, Ramašauskaitė $D$, Lūža $T$, Lenkutienė $R$. Pregnancy induced autoimmune warm antibodies hemolytic anemia: A case report. Geburtshilfe Frauenheilkd 2015; 75: 1167-1171.

6. Agarwal V, Sachdev A, Singh R, Lehl S, Basu S. Autoimmune hemolytic anemia associated with benign ovarian cyst: a case report and review of literature. Indian J Med Sci 2003; 57: 504-506.

7. Raimundo PO, Coelho S, Cabeleira A, Dias L, Goncalves M, Almeida J. Warm antibody autoimmune hemolytic anemia associated with ovarian teratoma. BMJ Case Rep 2010; 2010: bcr06.2009.1971.

8. West-Watson WN, Young CJ. Young CJ. Failed splenectomy in acholuric jaundice and the relation of toxaemia to the hemolytic crisis. BMJ 1938; 1 (4041): 1305-1309.

9. Payne D, Muss HB, Homesley HD, Jobson VW, Baird FG. Autoimmune hemolytic anemia and ovarian dermoid cysts: case report and review of the literature. Cancer 1981; 48: 721-724.

10. Sokol RJ, Hewitt S, Stamps BK. Erythrocyte autoantibodies, autoimmune haemolysis and pregnancy. Vox Sang 1982; 43 : $169-176$. 